JMI Vol. 40 No. 1 Juni 2018

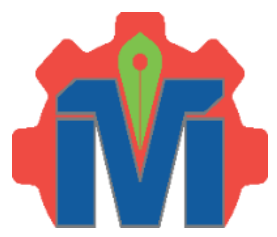

METAL INDONESIA

\title{
PENGARUH KARBON TERHADAP PERUBAHAN STRUKTUR MIKRO DAN SIFAT MEKANIK BAJA MANGAN AUSTENITIK
}

\section{THE EFFECT OF CARBON ON MICROSTRUCTURE AND MECHANICAL PROPERTIES OF AUSTENITIC MANGANESE STEELS}

\author{
Eko Pujiyulianto ${ }^{1)}$, Sri Bimo Pratomo ${ }^{2)}$, Pawawoi ${ }^{1)}$ \\ ${ }^{1)}$ Fakultas Teknik Jurusan Teknik Metalurgi Universitas Jenderal Achmad Yani, Jl. Jendral Gatot \\ Soebroto PO BOX 807 Bandung \\ E-mail : ekopuji39@gmail.com, pwawoi@gmail.com \\ 2) Balai Besar Logam dan Mesin, Jl. Sangkuriang No. 12 Kota Bandung 40135 \\ E-mail : bimo_bblm@yahoo.com
}

\begin{abstract}
Abstrak
Penelitian ini bertujuan untuk mengetahui pengaruh penambahan unsur karbon (C) terhadap struktur mikro dan sifat mekanik baja mangan. Baja mangan dengan kandungan mangan (Mn) sebesar 14\%, divariasikan dengan kandungan karbon $0,4 \%-1,6 \%$. Sampel akan dianalisis struktur mikro serta diuji sifat mekaniknya, yang meliputi : kekerasan, ketahanan aus, ketahanan impak dan kekuatan tarik. Hasil pengujian kekerasan menunjukkan bahwa rata rata kekerasan sampel tidak mengalami perubahan yang signifikan, yaitu sebesar $24 \mathrm{HRc}$ dengan rata-rata kekerasan fasa austenit sebesar 34 HRc dan fasa karbida sebesar $52 \mathrm{HRc}$. Hasil pengujian ketahanan aus memperlihatkan bahwa seiring dengan meningkatnya kandungan karbon maka ketahanan ausnya akan semakin meningkat. Persentase kehilangan berat terkecil terdapat pada kandungan karbon 1,6\% sebesar 0,01\%. Kekuatan impak dan elongasi meningkat pada kandungan karbon 0,4\%-1\% dan menurun pada kandungan karbon 1,4\%-1,6\%. Kekuatan impak paling tinggi pada kandungan karbon 0,7\% dan $1 \%$ sebesar 187 joule dan 167 joule, dengan elongasi $37,7 \%$ dan 38,2\%. Pada kandungan karbon $0,4 \%-1 \%$ nilai kekuatan tariknya meningkat seiring dengan meningkatnya kandungan karbon. Namun nilai kekuatan tarik menurun ketika kandungan karbon lebih dari 1\%. Baja mangan dengan kandungan karbon antara 0,7\%-1\% memiliki kombinasi kekuatan impak, elongasi dan kekuatan tarik yang tinggi. Baja mangan dengan kandungan karbon $0,7 \%$ dan $1 \%$ memiliki senyawa karbida yang paling sedikit, sehingga memiliki nilai ketahanan impak, elongasi dan kekuatan tarik yang tinggi.
\end{abstract}

Kata kunci : Baja mangan, karbon, struktur mikro, sifat mekanik

\begin{abstract}
This study aims is to determine the effect of carbon $(C)$ content to the microstructure and mechanical properties of Manganese steel. Manganese steel with $14 \%$ of manganese content varied with carbon content between $0.4 \%$ to $1.6 \%$. The microstructure sample will be analyzed and mechanical properties will be tested, including hardness, wear resistance, impact resistance and tensile strength. The result show that the hardness average not significantly change and gives hardness value $24 \mathrm{HRc}$, with austenite hardness average value $34 \mathrm{HRc}$ and carbide phase value 52 HRc. The results of wear resistance tests show that with increasing the carbon content, the wear resistance will be increased as well. The smallest percentage of weight loss in $1.6 \%$ carbon content is $0.01 \%$. Impact strength and elongation increased at carbon content $0.4 \%$ to $1 \%$, and decreased in $1.4 \%$ to $1.6 \%$ of carbon content. The highest impact strength is in the carbon content $0.7 \%$ and $1 \%$ which have 187 joules and 167 joules with elongation $37.7 \%$ and $38.2 \%$. Tensile strength increase with increasing carbon content from $0.4 \%$ - $1 \%$, but tensile strength decrease when carbon content is more than 1\%. Manganese steels with carbon content between $0.7 \%$ to $1 \%$ have a combination of impact strength, elongation and high tensile strength. . Manganese steels with carbon content of 0.7 and $1 \%$ have the least carbide, which the impact resistance, elongation and tensile strength gives the highest value.
\end{abstract}




\section{PENDAHULUAN}

Baja Mangan Austenitik (BMA) adalah baja paduan yang memiliki nilai ketangguhan yang tinggi (Akuan 2010), ketahanan aus yang baik (Lencina dkk. 2015) dan kekerasan yang baik apabila mengalami deformasi plastis (work hardening) (Xiong dkk. 2015), sehingga aplikasinya banyak dimanfaatkan untuk peralatan-peralatan yang mengalami beban impak yang besar dan keausan yang tinggi, seperti: bucket (Akuan 2010), crusher (Lencina dkk. 2015), hammer mill, rail crusher dan jaw Crusher (Olawale, Ibitoye and Shittu 2013).

Pemakaian BMA sering mengalami permasalahan di lapangan, yaitu umur pakai yang tidak sesuai dengan rencana desain, sehingga menyebabkan kegagalan komponen seperti yang terjadi di beberapa industri pertambangan (Lencina dkk. 2015; Olawale, Ibitoye and Shittu 2013). Parameter yang paling berpengaruh terhadap sifat mekanik BMA adalah bentuk struktur mikro (Mahlami and Pan 2014; Akuan 2010), komposisi kimia (Lencina dkk. 2015) dan proses heat treatment (Tęcza and Sobula 2014; Akuan 2010). Beberapa penelitian terkait pengaruh variasi komposisi kimia pernah dilakukan dengan memvariasikan kandungan karbon (C) sebesar 0,2\%,0,4\%, dan $0,6 \%$, dan kandungan mangan (Mn) $22 \%$ terhadap sifat mekanik dan struktur mikro (Ghasri-Khouzani and McDermid 2015), lalu pernah dilakukan penelitian mengenai pengaruh variasi unsur silikon sebesar 3\%, 5\%, dan $6 \%$ dengan perbandingan unsur karbon (C) $0,3 \%$, $0,5 \%, 0,6 \%$ dengan mangan $(\mathrm{Mn}) 17 \%$ dan $1 \%$ karbon dengan kandungan mangan 13\% terhadap stacking fault energy dan work hardening (Xiong dkk. 2015), selain unsur karbon pernah dilakukan penelitian untuk mengetahui pengaruh variasi kandungan molibdenum (Mo) terhadap karakteristik BMA (Mohammadnezhad and Javaheri 2013; Razavi, Rizi, and Zadeh 2013), variasi kandungan Cr, dan Ti terhadap wear resistence (Kalandyk dkk. 2015), variasi kandungan $\mathrm{Cr}$ terhadap sifat mekanik baja mangan (Tęcza and Sobula 2014), dan pengaruh kandungan $\mathrm{Cr}, \mathrm{P}$, dan $\mathrm{Si}$ dengan kandungan karbon $1,2 \% \mathrm{C}-1,6 \% \mathrm{C}$ terhadap sifat mekanik baja mangan (Mahlami and Pan 2014), dan pengaruh inokulasi Mo dan $\mathrm{Ni}$ terhadap fenomena work hardening (Res dkk. 2016).
Komposisi kimia sangat berpengaruh terhadap sifat mekanik BMA. Penelitian terkait proses heat treatment pada baja mangan austenit pernah dilakukan untuk mengetahui pengaruh proses annealing, normalizing, dan quenching terhadap struktur mikro dan sifat mekanik baja mangan austenite (Tęcza and Sobula 2014; Akuan 2010). Penelitian ini mencoba memvariasikan kandungan karbon dengan variasi komposisi yang lebih banyak yaitu $0,4 \%, 0,7 \%, 1,0 \%, 1,4 \%, 1,6 \%$ dan kandungan mangan $14 \%$, untuk mengetahui pengaruh unsur karbon terhadap struktur mikro dan sifat mekanik Baja Mangan Austenite (BMA), serta mendapatkan perbandingan kandungan karbon dan mangan dengan kombinasi sifat mekanik yang optimal. Pada penelitian ini dilakukan penambahan pengujian mekanik yaitu pengujian impak yang belum pernah dilakukan pada pengujian sebelumnya.

\section{METODE PENELITIAN}

Langkah langkah metode penelitian yang dilakukan adalah sebagai berikut :

1. Pengecoran

2. Spektrometri

3. Permesinan

4. Heat treatment

5. Pengujian mekanik

6. Struktur mikro (metalografi kualitatif)

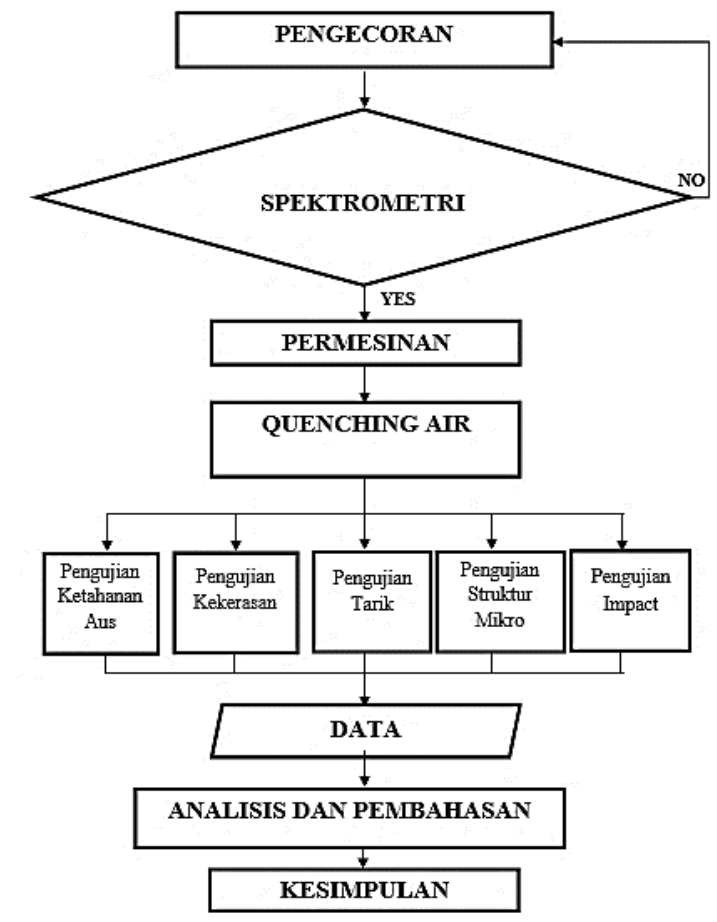


Gambar 1. Skema penelitian

Deskripsi langkah penelitian yang dilakukan adalah :

\section{Pengecoran}

Proses pengecoran meliputi proses pembuatan pola, pembuatan cetakan pasir, proses peleburan, proses pengambilan sampel uji komposisi (spektrometri) dan proses penuangan logam cair ke dalam cetakan pasir. Proses peleburan menggunakan tungku induksi (Soljer $J I C A$ ) dengan memanfaatkan medan magnet yang dihasilkan oleh coil dan dialiri arus listrik. Kapasitas tungku sebesar 200 kg. Paduan logam yang akan dibuat adalah lima jenis paduan BMA yang divariasikan unsur karbonnya dengan variasi $0,4 \%, 0,7 \%, 1,0 \%, 1,4 \%, 1,6 \%$ dan sisanya adalah $\mathrm{Mn} 14 \% ; \mathrm{Si} 0,9 \%$; Mo 0,07\%; P 0,05\%; S 0,006\%; Cr 0,75\%; Ni $0,13 \%$. Proses penuangan dilakukan pada temperatur $1550{ }^{\circ} \mathrm{C}$ dengan waktu penuangan selama 6 - 7 detik. Proses pengecoran dilakukan di laboratorium teknik pengecoran logam BBLM (Balai Besar Logam dan Mesin) Bandung.

\section{Spektrometri}

Pengujian spektrometri adalah pengujian untuk mengetahui komposisi kimia pada material yang dilakukan di laboratorium teknik pengecoran logam BBLM (Balai Besar Logam dan Mesin) Bandung. Pengujian spektrometri menggunakan spektrometer jenis ARUN polyspak series.

\section{Permesinan}

Pemesinan merupakan proses preparasi spesimen untuk membuat spesimen uji meliputi spesimen uji impak, keausan, kekerasan, tarik, dan struktur mikro. Proses pemesinan yang dilakukan adalah turning dengan conventional turning machine DoALL 13" dan milling dengan conventional milling machine $G$ Dufour. Proses permesinan dilakukan di B4T (Balai Besar Bahan dan Barang Teknik) Bandung.

\section{Heat treatment}

Perlakuan panas yang dilakukan adalah Quenching air. Quenching air merupakan jenis perlakuan panas yang terdiri dari pemanasan hingga temperatur austenisasi, penahanan beberapa menit lalu didinginkan dengan menggunakan media air (Akuan 2010). Temperatur austenisasi untuk paduan $\mathrm{Fe}-\mathrm{C}-\mathrm{Mn}$ ini berkisar antara $1000-1100^{\circ} \mathrm{C}$ (Akuan 2010). Pada penelitian ini temperatur austenisasi yang digunakan adalah $1050{ }^{\circ} \mathrm{C}$ dengan skema proses heat-treatment seperti pada gambar.2. Proses heat treatment dilakukan pada tungku heat treatment jenis furnace SOLJER JICA di laboratorium teknik pengecoran logam BBLM (Balai Besar Logam dan Mesin) Bandung.

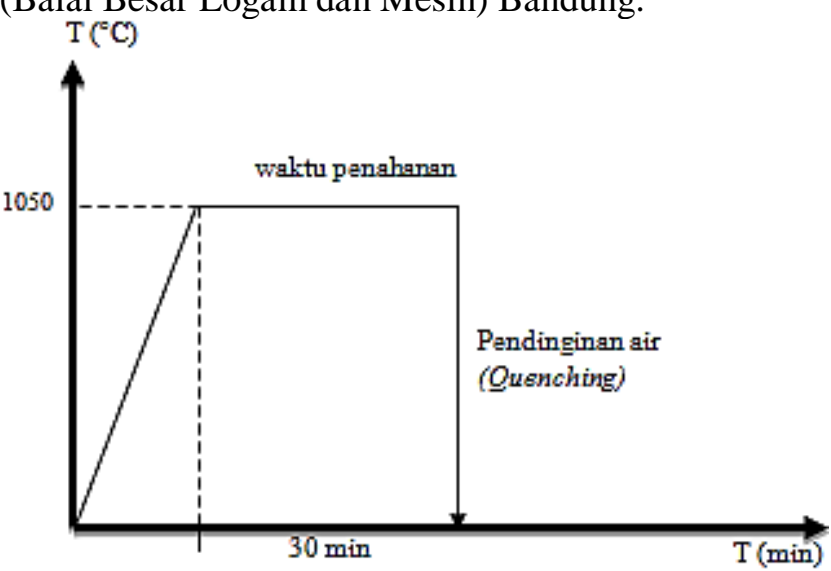

Gambar 2. Skema proses heat treatment

5. Pengujian mekanik

a. Pengujian keausan

Pengujian keausan dilakukan dengan menggesekkan permukaan spesimen uji pada ring disk dengan beban $5 \mathrm{~kg}$ selama 1 jam. Kemudian dihitung besarnya persentase kehilangan massa spesimen uji. Metode pengujian keausan dilakukan dengan menggunakan metode block on ring pada mesin neoplus BRW 140.

b. Pengujian impak

Pengujian impak bertujuan untuk mengetahui sifat dari suatu material bahwa material bersifat getas atau ulet, adapun kegetasan dan keuletan dapat menginterpretasikan ketangguhan. Ketangguhan didefinisikan sebagai kemampuan dari suatu material untuk menyerap energi. Pengujian ketangguhan (uji impak) yang dilakukan di B4T (Balai Besar Bahan dan Barang Teknik) yang mengacu pada standar JIS Z 2242 dengan menggunakan mesin uji impak jenis pendulum impak test zwick roell PSW 750 dan spesimen yang digunakan untuk pengujian ini mengacu pada 
standar JIS Z 2202 (“JIS (Japanese Industrial Standard)," n.d.).

c. Pengujian tarik

Pengujian tarik bertujuan untuk memberikan informasi mengenai sifat mekanik dari material. Pengujian tarik dilakukan di B4T (Balai Besar Bahan dan Barang Teknik) yang mengacu pada standar JIS Z 2241 dengan menggunakan mesin uji tarik jenis tensile test zwick roell Z010, dan spesimen yang digunakan mengacu pada standar JIS Z 2201 ("JIS (Japanese Industrial Standard)," n.d.).

d. Pengujian kekerasan

Pengujian kekerasan yang digunakan adalah pengujian Rockwell $\mathrm{C}$ dengan menggunakan mesin hardness test Rockwell jenis AFFRI MRS ASTM E-18 dan pengujian Micro Vickers dengan microhardness test jenis AFFRI MRS ASTM E-384. Pengujian kekerasan Rockwell C mengacu pada standar JIS Z 2245 menggunakan indentor berupa kerucut intan dengan beban total sebesar 1471 N. Pengujian kekerasan Micro Vickers mengacu pada standar JIS Z 2244 menggunakan indentor piramida intan dengan beban $1 \mathrm{Kgf}$ Selama 10-15 detik. Pengujian kekerasan Micro Vickers ini bertujuan untuk mengetahui kekerasan secara spesifik dari fasa dan senyawa yang dihasilkan pada BMA.

e. Struktur mikro (metalografi kualitatif) Persiapan spesimen dan pengujian metalografi pada penelitian ini mengacu pada standar ASTM E3-01 dengan proses antara lain pemotongan, pengamplasan, pemolesan, pengetsaan dan pengamatan struktur mikro. Kertas amplas yang digunakan berurutan dari kekasaran ANSI 80, 120, 220, 400, 600, $800,1000,1200,1500$ hingga 2000 mesh, lalu polishing. Pada penelitian ini, larutan etsa yang digunakan adalah larutan Nital 3\% (3 $\mathrm{ml} \mathrm{HNO}_{3}$ dalam 97 $\mathrm{ml}$ alcohol).

Pengamatan dan pemotretan struktur mikro dilakukan dengan Scanning Electron Microscopy (SEM) Hitachi SU-3500. Pengujian struktur mikro dilakukan di LIPI Serpong.

\section{HASIL DAN PEMBAHASAN}

Bagian ini berisi hasil dan pembahasan dari alur proses dan pengujian yang telah dilakukan.

1. Hasil Proses Pengecoran dan pengujian spektrometri.

Proses pengecoran dan pengujian spektrometri menghasilkan BMA dengan komposisi seperti pada tabel 1, pada tabel tersebut menunjukan bahwa komposisi kimia hasil proses pengecoran sesuai dengan komposisi kimia rencana cor, yaitu 0,4\%. 0,7\%. $1,0 \% .1,4 \% .1,6 \%$ unsur karbon dan kandungan mangan 14\% (Tabel 1).

Tabel 1. Komposisi kimia BMA hasil Proses pengecoran

\begin{tabular}{|c|c|c|c|c|c|}
\hline \multirow{2}{*}{ Unsur } & \multicolumn{5}{|c|}{ Komposisi Unsur Paduan Spesimen (\%) } \\
\cline { 2 - 6 } & Mn 1 & Mn 2 & Mn 3 & Mn 4 & Mn 5 \\
\hline Fe & 83,64 & 83,52 & 83,29 & 83,14 & 82,68 \\
\hline $\mathbf{C}$ & 0,428 & 0,656 & 1,040 & 1,350 & 1,630 \\
\hline $\mathbf{S i}$ & 0,867 & 0,950 & 0,971 & 0,918 & 0,992 \\
\hline $\mathbf{M n}$ & 13,97 & 13,73 & 13,56 & 13,45 & 13,58 \\
\hline $\mathbf{P}$ & 0,053 & 0,055 & 0,057 & 0,055 & 0,055 \\
\hline $\mathbf{S}$ & $<0,002$ & 0,005 & 0,006 & 0,006 & 0,006 \\
\hline $\mathbf{C r}$ & 0,752 & 0,777 & 0,769 & 0,765 & 0,749 \\
\hline $\mathbf{M o}$ & 0,040 & 0,074 & 0,076 & 0,078 & 0,075 \\
\hline $\mathbf{N i}$ & 0,129 & 0,126 & 0,127 & 0,128 & 0,120 \\
\hline $\mathbf{A l}$ & 0,002 & 0,003 & 0,003 & 0,003 & 0,002 \\
\hline $\mathbf{C u}$ & $<0,001$ & $<0,001$ & $<0,001$ & $<0,001$ & $<0,001$ \\
\hline $\mathbf{V}$ & 0,008 & 0,008 & 0,004 & 0,007 & 0,005 \\
\hline
\end{tabular}

2. Pengujian keausan

Pengujian ketahanan aus dari baja mangan asutenitik di tunjukan pada gambar 3 . Grafik pada gambar 3 menunjukan bahwa seiring dengan meningkatnya kandungan karbon (C) maka ketahanan aus dari BMA semakin meningkat. pada kandungan 0,4\%C dihasilkan persentase kehilangan masa sebesar $0,8 \%, 0,7 \% \mathrm{C}$ sebesar $0,64 \%, 1,0 \% \mathrm{C}$ sebesar $0,1 \%, 1,4 \% \mathrm{C}$ sebesar $0,02 \%$, dan pada $1,6 \% \mathrm{C}$ didapatkan persentase kehilangan berat sebesar $0,01 \%$ (Gambar 3).

Data pengujian keausan menunjukan ketahanan aus yang paling baik dimiliki oleh BMA dengan komposisi 1,4\% C dan 1,6\%C, hal ini disebabkan oleh kehadiran senyawa carbida yang getas serta bentuknya yang lebih besar di bandingkan dengan BMA dengan komposisi 0,4\%-1,0\%C (Gambar 11). 


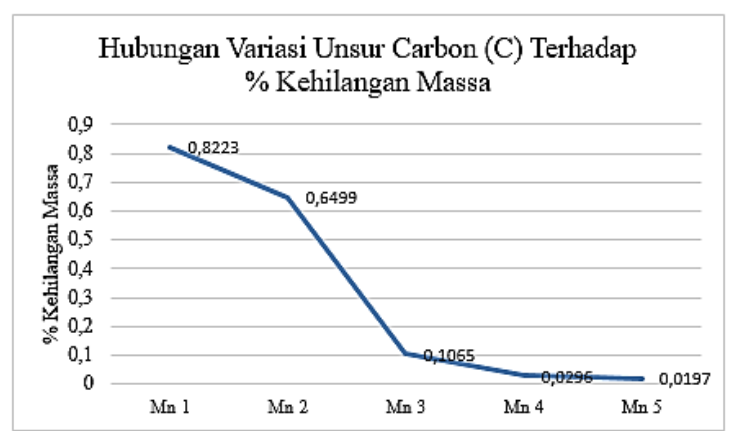

Gambar 3. Pengaruh variasi unsur Karbon terhadap ketahanan aus BMA.

\section{Pengujian impak}

Hasil pengujian impak baja mangan austenitik ditunjukan pada gambar 4. Pengujian impak dengan metode charphy menunjukan kandungan karbon berpengaruh terhadap harga impak baja Mangan austenitik. Pengaruh tersebut dapat dilihat dari perbedaan harga impak yang berbeda untuk masing masing komposisi, dan dari bentuk permukaan patah specimen hasil pengujian impak secara makro (gambar 5).

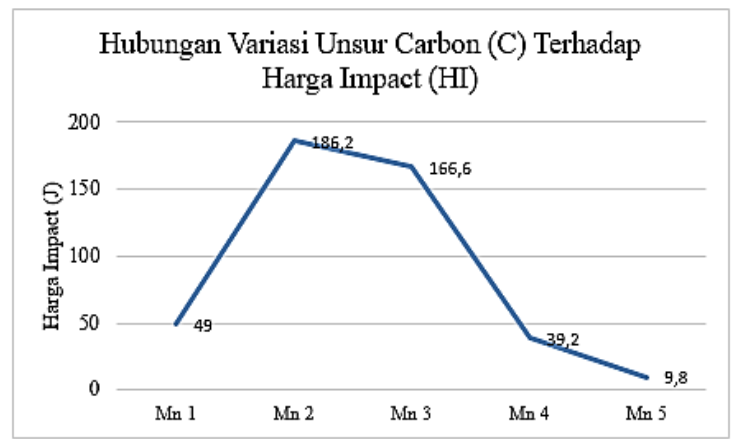

Gambar 4. Pengaruh variasi unsur Karbon terhadap kekuatan impak BMA.

BMA yang memiliki harga impak paling tinggi adalah BMA dengan kandungan karbon 0,7\% dan 1,0\%C sebesar 186,2 J dan 166,6 J sedangkan BMA yang memiliki harga impak yang paling rendah adalah BMA dengan kandungan karbon $1,6 \% \mathrm{C}, 1,4 \% \mathrm{C}$, dan $0,4 \% \mathrm{C}$ dimana harga impaknya 9,8 J, 39,2 J, dan $49 \mathrm{~J}$ (Gambar 4). Kekuatan impak merupakan kemampuan suatu material untuk menyerap energi, semakin ulet material maka kemampuan untuk menyerap energi semakin baik. Permukaan patahan untuk BMA dengan kandungan karbon $0,7 \% \mathrm{C}$ dan $1,0 \% \mathrm{C}$ memiliki bentuk permukaan patah yang lebih ulet yang ditandai oleh terbentuknya serabut akibat deformasi yang besar sebelum BMA mengalami patah, berbeda halnya dengan bentuk permukaan patahan pada BMA dengan kandungan karbon $1,6 \% \mathrm{C}, 1,4 \% \mathrm{C}$ dan $0,4 \% \mathrm{C}$ yang memiliki sedikit serabut pada permukaan patahannya sehingga deformasi yang terjadi pada BMA ini sangat kecil. Pada gambar 5 di tunjukan perbandingan permukaan patah antara material yang mengalami patah getas (b) $1,6 \%$ $\mathrm{C}$ dan patah ulet (a) $0,7 \% \mathrm{C}$.

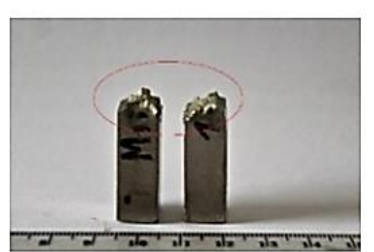

(a)

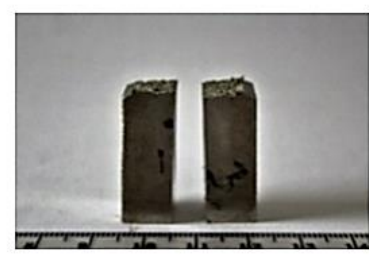

(b)
Gambar 5. Permukaan patah BMA hasil pengujian impak.

Harga impak berbanding lurus dengan besarnya elongasi dari pengujian tarik. Elongasi yang paling besar adalah BMA dengan kandungan $0,7 \% \mathrm{C}$ dan $1,0 \% \mathrm{C}$ yaitu sebesar $37,7 \%$ dan 38,2\% elongasi (Gambar 8), sedangkan BMA yang memiliki elongasi paling rendah adalah BMA dengan kandungan karbon $1,6 \% \mathrm{C}, 0,4 \% \mathrm{C}$ dan $1,4 \% \mathrm{C}$ yaitu sebesar $6 \%$, $7,90 \%$ dan $13,5 \%$ elongasi (Gambar 8). Harga impak dan besarnya elongasi diatas menujukan bahwa BMA dengan kandungan karbon 0,7\%C dan $1,0 \% \mathrm{C}$ memiliki keuletan yang jauh lebih baik di bandingkan dengan BMA yang memiliki kandungan karbon $1,6 \% \mathrm{C}, 0,4 \% \mathrm{C}$ dan $1,4 \%$ C. Dilihat dari hasil pengujian struktur mikro pada gambar 11 bahwa BMA dengan kandungan karbon $0,7 \% \mathrm{C}$ dan 1,0\% $\mathrm{C}$ memiliki sedikit karbida di bandingkan BMA dengan kandungan karbon 1,6\% C, 0,4\%C dan 1,4\%C, ketidakhadiran karbida pada BMA dapat meningkatkan kekuatan impak, ketangguhan, serta keulatan BMA, hal ini di sebabkan oleh karbida yang memiliki kekerasan yang tinggi, dimana terjadi pada material BMA dengan kandungan karbon $1,6 \% \mathrm{C}, 0,4 \% \mathrm{C}$ dan $1,4 \% \mathrm{C}$ yang memiliki karbida lebih banyak dibandingkan BMA dengan kandungan Karbon $0,7 \% \mathrm{C}$ dan $1,0 \%$ C. Sedikitnya karbida yang terbentuk menyebabkan fasa austenit sebagai matriks lebih banyak perbandinganya, sifat dari austenit yang lunak menyebabkan BMA dengan kandungan $0,7 \% \mathrm{C}$ dan $1,0 \% \mathrm{C}$ memiliki keuletan, ketangguhan, serta kekuatan impak yang sangat baik.

4. Pengujian tarik 
Dari hasil pengujian tarik didapatkan beberapa sifat mekanik material seperti kekuatan tarik (gambar 6), kekuatan luluh (gambar 7), dan elongasi (gambar 7). Dari hasil pengujian tarik dapat dilihat pada gambar 6,7, dan 8 bahwa kandungan karbon berpengaruh terhadap sifat mekanik baja mangan austenitik.

Pada gambar 7 dapat dilihat bahwa semakin meningkatnya unsur karbon maka kekuatan luluh BMA meningkat. Kekuatan luluh masing masing BMA dengan kandungan karbon 0,4\%, $0,7 \%, 1,0 \%, 1,4 \%$, dan $1,6 \%$ adalah $188,2 \mathrm{MPa}$, 339,1 $\mathrm{MPa}, 405,8 \mathrm{MPa}, 446,5 \mathrm{Mpa}$, dan 462,3 Mpa, kekuatan luluh paling besar dimiliki oleh BMA dengan kandungan karbon 1,6\%C.

Berbeda halnya dengan kekuatan tarik BMA, pada gambar 6 dapat dilihat bahwa kekuatan tarik BMA meningkat pada kandungan karbon $0,4 \% \mathrm{C}$ sampai $1,0 \% \mathrm{C}$, dan kekuatan tarik BMA menurun pada kandungan karbon $1,4 \% \mathrm{C}$ sampai $1,6 \% \mathrm{C}$, kekuatan tarik maksimum dimiliki oleh BMA dengan kandungan karbon $1,0 \% \mathrm{C}$ yaitu sebesar $728 \mathrm{MPa}$, sedangkan untuk $0,4 \% \mathrm{C}, \quad 0,7 \% \mathrm{C}, 1,4 \% \mathrm{C}$, dan $1,6 \% \mathrm{C}$ memiliki kekuatan tarik 489,10 Mpa, 676,3 Mpa, 654,58 Mpa dan 633,3 Mpa (Gambar 6).

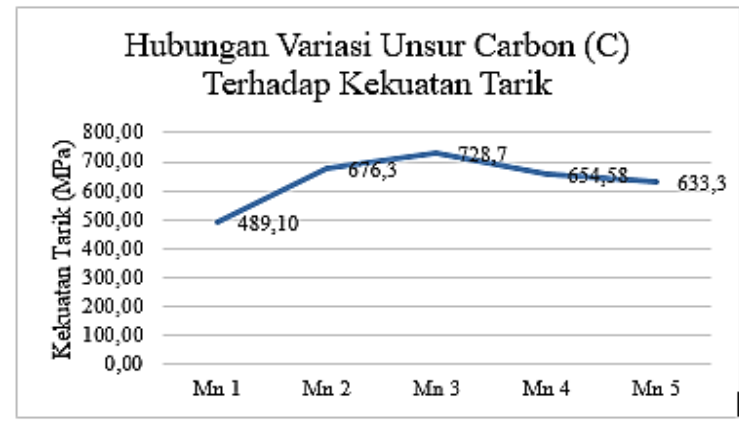

Gambar 6. Pengaruh variasi unsur karbon terhadap kekuatan tarik BMA.

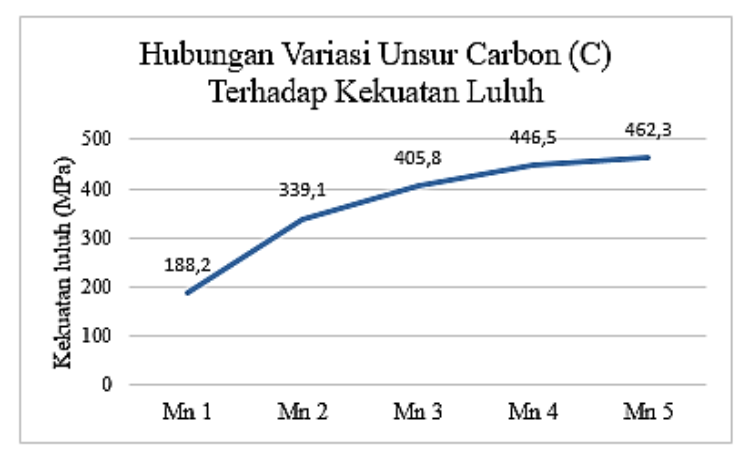

Gambar 7. Pengaruh variasi unsur karbon terhadap kekuatan luluh BMA.
Selain dua sifat utama diatas, besarnya elongasi dari pengujian tarik baja Mangan austenitik ditampilkan pada gambar 8 .

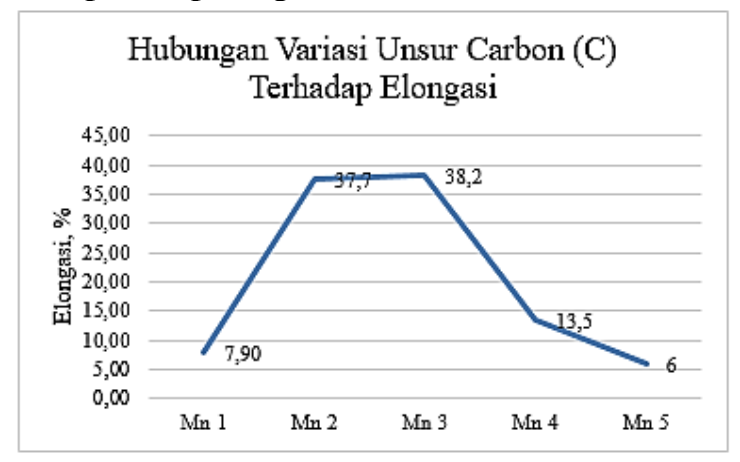

Gambar 8. Pengaruh variasi unsur karbon terhadap elongasi BMA.

Material yang memiliki elongasi paling tinggi adalah baja mangan austenitik dengan kandungan karbon $1 \%$ sebesar 38,2\% elongasi, diikuti oleh BMA dengan kandungan karbon $0,6 \% \mathrm{C}$ sebesar $37,7 \%$ elongasi, $1,4 \% \mathrm{C}$ sebesar $13,5 \%$ elongasi, $0,4 \% \mathrm{C}$ sebesar $7,8 \%$ elongasi, dan $1,6 \% \mathrm{C}$ sebesar $6 \%$ elongasi (Gambar 8). Perbedaan nilai dari elongasi diperjelas dengan bentuk permukaan hasil pengujian tarik. Dilihat dari permukaan patah secara makro hasil pengujian tarik BMA dengan kandungan karbon $0,6 \% \mathrm{C}$ dan $1,0 \% \mathrm{C}$ memiliki bentuk permukaan patah yang lebih berserabut (fibrous \& irreguler ineterior) (Gambar 5) dibandingkan dengan BMA dengan kandungan karbon $0,4 \% \mathrm{C}, 1,4 \% \mathrm{C}$, dan $1,6 \% \mathrm{C}$. Hal ini menunjukan bahwa BMA dengan kandungan karbon $0,6 \% \mathrm{C}$ dan $1,0 \% \mathrm{C}$ memiliki sifat yang lebih ulet dibandingkan BMA dengan kandungan karbon $0,4 \% \mathrm{C}, 1,4 \% \mathrm{C}$, dan 1,6\%C. BMA dengan kandungan karbon $0,4 \%$ bersifat getas, walaupun dengan kandungan karbon yang sedikit, hal ini disebabkan oleh kehadiran senyawa karbida pada material tersebut dibandingkan dengan $0,6 \% \mathrm{C}$, dan $1 \% \mathrm{C}$ yang memiliki sedikit senyawa karbida (gambar 11), bahkan pada $1 \% \mathrm{C}$ senyawa karbida hampir larut (gambar 11).

Pada permukaan patah BMA secara makro, BMA dengan kandungan karbon $0,6 \% \mathrm{C}$ dan 1,0\% C mengalami mekanisme cup \& cone, sedangkan pada BMA dengan kandungan karbon $0,4 \% \mathrm{C}, 1,4 \% \mathrm{C}$, dan $1,6 \% \mathrm{C}$ tidak mengalami mekanisme cup\&cone disebabkan oleh patah yang terjadi adalah patah getas. Pada gambar 9 di tunjukan perbandingan permukaan 
patah antara material yang mengalami patah getas (a) $1,6 \% \mathrm{C}$ dan patah ulet (b) $0,7 \% \mathrm{C}$.

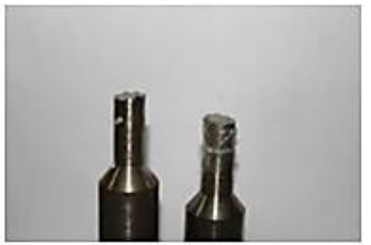

(a)

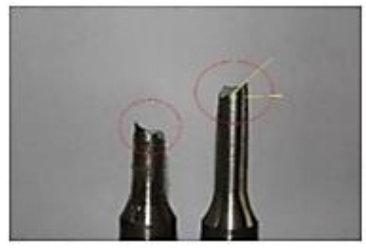

(b)
Gambar 9. Permukaan patah hasil pengujian tarik BMA.

Pada gambar diatas terlihat jelas terbentuknya serabut yang membentuk sudut $45^{\circ}$ akibat shear deformation, sudut $45^{\circ}$ menunjukan bahwa tegangan geser yang terjadi merupakan tegangan geser maskimum.

\section{Pengujian kekerasan}

Pengujian kekerasan pada bagian 5 merupakan pengujian untuk mengukur kekerasan material dengan menggunakan metode Rockwell C, berbeda halnya pada bagian 6 dimana pengujian kekerasan dilakukan untuk mengetahui kekerasan senyawa dan fasa pada material dengan menggunakan metode microvikers.

Hasil pengujian kekerasan material ditunjukan oleh grafik pada gambar 10. Grafik tersebut menunjukan bahwa kandungan karbon tidak berpengaruh terhadap kekerasan baja mangan austenitik hasil proses pendinginan air (quenching).

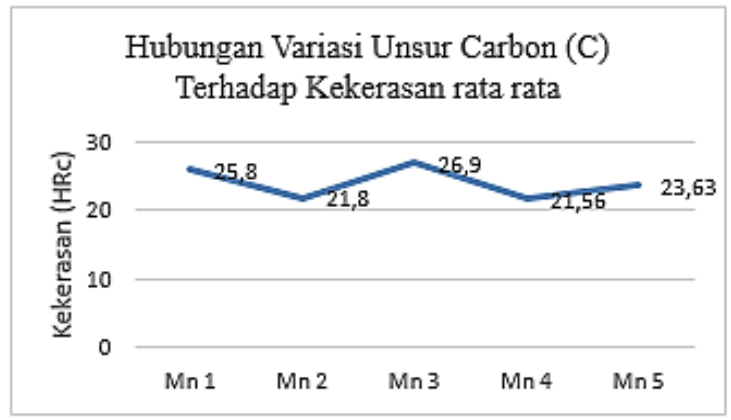

Gambar 10. Pengaruh variasi unsur karbon terhadap kekerasan BMA.

Pada gambar 10 dapat dilihat bahwa interval kekerasan BMA berada diantara 21-26 HRc, nilai kekerasan yang tidak terlalu jauh disebabkan oleh matrik pada BMA adalah austenit, sehingga penambahan unsur karbon (C) tidak merubah kekerasan BMA secara signifikan karena matriks fasa pada BMA adalah austenit.
Kekerasan BMA tidak berhubungan dengan besarnya elongasi seperti material pada umumnya. Perbedaan nilai elongasi disebabkan oleh kehadiran senyawa karbida dan mekanisme work hardening ketika terjadi deformasi pada material. Work hardening merupakan mekanisme penguatan pada logam akibat adanya deformasi plastis, sedangkan nilai kekerasan BMA ditentukan oleh matriks dari fasa austenit.

6. Pemeriksaan struktur mikro

Hasil pemeriksaan struktur mikro dengan menggunakan SEM ditunjukan pada gambar 11. Pada gambar 11 dapat dilihat bahwa perbedaan kandungan karbon berpengaruh terhadap bentuk struktur mikro baja mangan austenit.

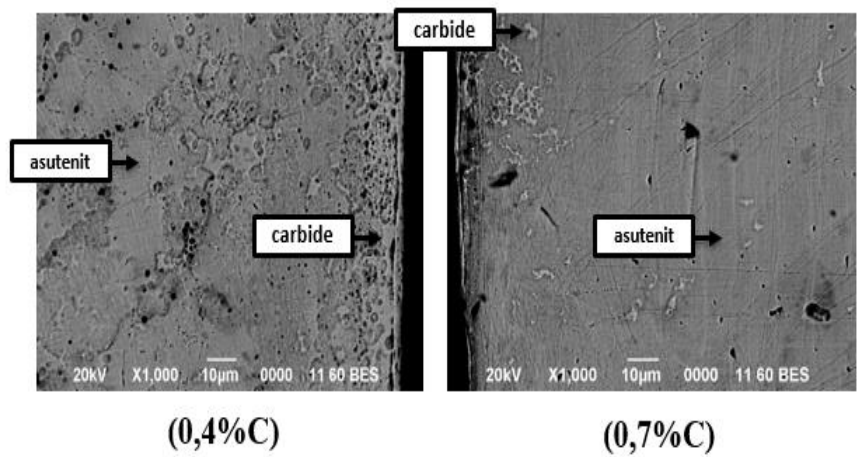

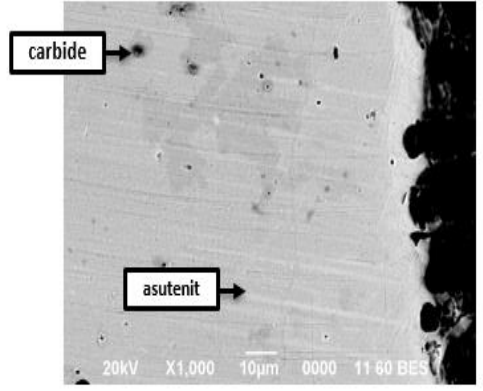

$(1,0 \% \mathrm{C})$

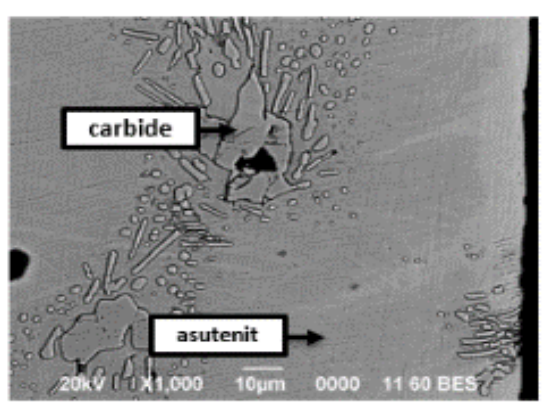

$(1,6 \% C)$

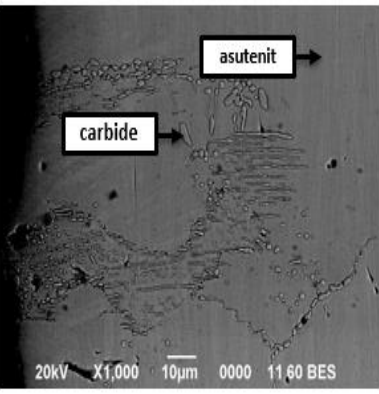

$(1,4 \% \mathrm{C})$
Gambar 11. Struktur Mikro hasil pengujian SEM. 
Dari hasil pengujian struktur mikro BMA dihasilkan fasa matriks austenit dan karbida seperti pada gambar 11, fasa austenit dihasilkan pada temperatur kamar disebabkan oleh unsur Mn (Mangan) yang tinggi, unsur Mn (Mangan) bertindak sebagai austenit former, sedangkan karbida terbentuk akibat pendinginan yang tidak seragam (Akuan 2010; Mahlami and Pan 2014) sehingga mengalami pendinginan lambat. Pengaruh unsur karbon (C) terhadap struktu mikro adalah semakin meningkatnya kandungan karbon dari $0,4 \%-1,0 \%$ pada BMA volume kehadiran karbida semakin berkurang, sedangkan pada BMA dengan komposisi karbon 1,4\% karbida tumbuh kembali dan membesar pada komposisi karbon 1,6\% (gambar 11) alasan berkurangnya kehadiran karbida pada kandungan karbon $1 \%$ dari kehadiran karbida pada kandungan 0,4\% C secara lebih mendalam tidak dijelaskan pada penelitian ini, namun menurut (Pratomo 2016) bahwa menurunya kehadiran karbida dengan meningkatnya kandungan karbon dari 0,4\% $1,0 \%$ disebabkan oleh naiknya garis solidus pembentukan fasa ferrit pada diagram fasa biner $\mathrm{Fe}-13 \% \mathrm{Mn}$ yang dimulai dari $0,2 \% \mathrm{C}-1,0 \%$ C (Pratomo 2016).

Senyawa karbida yang terbentuk merupakan senyawa karbida kompleks (Akuan 2010; Mahlami and Pan 2014) yang terbentuk akibat pendinginan yang tidak seragam dan beberapa carbide former yang terkandung didalam paduan (Herring 2015; Maalekian 2007; Tęcza and Sobula 2014).

Ketika dilakukan pengujian kekerasan pada fasa matriks austenit dan karbida, dari hasil pengujian kekerasan menggunakan microvikers dengan beban sebesar 1 kgf dihasilkan kekerasan rata rata karbida adalah 549,9 HVN (52 HRc) dan kekerasan rata rata fasa matriks austenit adalah 345,3 HVN (34 HRc) (Gambar 12). Perbedaan kekerasan antara fasa matrik austenit dengan karbida disebabkan oleh sifat dari masing masing fasa. Fasa austenit memiliki sifat yang lunak dan karbida memiliki sifat yang getas.

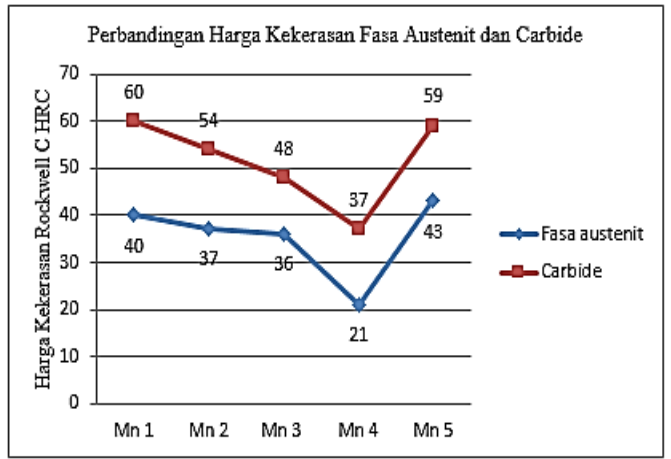

Gambar 12. Perbandingan kekerasan fasa austenit dan senyawa karbida

\section{KESIMPULAN}

Dari hasil penelitian dan pembahasan yang telah dilakukan, maka dapat ditarik kesimpulan sebagai berikut:

1. Struktur mikro Baja Mangan Austenitik (BMA) memiliki fasa austenit dan karbida, senyawa karbida (52 $\mathrm{HRc})$ memiliki kekerasan yang lebih tinggi dibandingkan fasa austenit (34 HRc). Namun kekerasan material BMA relative tidak berubah dengan variasi karbon $0,4 \% \mathrm{C}$ - $1,6 \% \mathrm{C}$ karena matrik dari BMA adalah austenit.

2. Meningkatnya kandungan karbon (C) dari $0,4 \%-1,0 \%$ C meningkatkan kekuatan tarik, kekuatan luluh, ketahanan aus, elongasi dan berkurangannya senyawa karbida pada BMA, tetapi kekuatan tarik, elongasi menurun, dan kehadiran senyawa karbida meningkat pada 1,4\% C-1,6\% C. Kekuatan luluh dan ketahanan aus BMA tetap meningkat pada $1,4 \% \mathrm{C}-1,6 \% \mathrm{C}$.

3. Meningkatnya kandungan karbon (C) dari $0,4 \%$ - $0,7 \%$ C meningkatkan kekuatan impak tetapi kekuatan impak menurun pada $1,0 \% \mathrm{C}-1,6 \%$.

\section{UCAPAN TERIMA KASIH}

Terima kasih kepada Dr.Eng Sri Bimo Pratomo,.M.Eng di Balai Besar Logam dan Mesin (BBLM) Bandung dan Pawawoi,.S.T, M.T. di Teknik Metalurgi UNJANI yang telah membantu dan menyelesaikan penelitian ini.

\section{DAFTAR PUSTAKA}

Akuan, Abrianto. 2010. "Analisis Struktur Mikro Dan Sifat Mekanik Baja Mangan Austenitik Hasil Proses Perlakuan 
Panas."

Ghasri-Khouzani, M., and J. R. McDermid. 2015. "Effect of Karbon Content on the Mechanical Properties and Microstructural Evolution of Fe-22Mn-C Steels." Materials Science and Engineering $A$ 621: 118-27. https://doi.org/10.1016/j.msea.2014.10.0 42.

Herring, Daniel H. 2015. "Influence of Alloying Elements on Austenite Classi Cation of Alloying Elements."

"JIS (Japanese Industrial Standard)." n.d.

Kalandyk, B., G. Tęcza, R. Zapała, and S. Sobula. 2015. "Cast High-Manganese Steel - the Effect of Microstructure on Abrasive Wear Behaviour in Miller Test." Archives of Foundry Engineering $15 \quad$ (2): 35-38. https://doi.org/10.1515/afe-2015-0033.

Lencina, Rodrigo, Claudia Caletti, Katya Brunelli, and Rodolfo Micone. 2015. "Assessing Wear Performance of Two High-Karbon Hadfield Steels Through Field Tests in the Mining Industry." Procedia Materials Science 9: 358-66. https://doi.org/10.1016/j.mspro.2015.05.0 05 .

Maalekian, Mehran. 2007. "The Effects of Alloying Elements on Steels (I)." The Effects of Alloying Elements on Steels 1 (October):

36.

https://doi.org/10.1016/S0026-

2714(98)00110-3.

Mahlami, C S, and X Pan. 2014. "An Overview on High Manganese Steel Casting." 71st World Foundary Congress: Advanced Sustainable Foundary 71 (5): 1-10. http://hdl.handle.net/10210/11557.

Mohammadnezhad, Mahyar, and Vahid Javaheri. 2013. "Effect of the Molybdenum on the Microstructural and Mechanical Properties of Hadfield Austenitic Manganese Steel Effect of the Molybdenum on the Microstructural and Mechanical Properties of Hadfield Austenitic Manganese Steel Introduction :," no. October.

Olawale, J. O., S. A. Ibitoye, and M. D. Shittu. 2013. "Workhardening Behaviour and Microstructural Analysis of Failed Austenitic Manganese Steel Crusher Jaws." Materials Research 16 (6): 1274 81. $\quad$ https://doi.org/10.1590/S151614392013005000144.
Pratomo, Sri Bimo. 2016. "Fakultas Teknik Jurusan Teknik Metalurgi Universitas Jenderal Achmad Yani."

Razavi, Gholam Reza, Mohsen Saboktakin Rizi, and Hossein Monajati Zadeh. 2013. "Effect of a Mo Addition on the Properties of High-Mn Steel." Materiali in Tehnologije 47 (5): 611-14.

Res, J Mater, Hichem Maouche, Ali Hadji, and Khadija Bouhamla. 2016. "Effect of Inoculation by Molybdenum and Nickel on Hardening Phenomenon and Wear Behavior of High Manganese Steel," no. 3: $1-8$.

Tęcza, G, and S Sobula. 2014. "Effect of Heat Treatment on Change Microstructure of Cast High-Manganese Hadfield Steel with Elevated Chromium Content," 6770.

Xiong, Renlong, Huabei Peng, Shanling Wang, Haitao Si, and Yuhua Wen. 2015. "Effect of Stacking Fault Energy on Work Hardening Behaviors in Fe-Mn-Si-C High Manganese Steels by Varying Silicon and Karbon Contents." Materials and Design 85: 707-14. https://doi.org/10.1016/j.matdes.2015.07. 072. 